\title{
COLLABORATIONS AND RENEGOTIATIONS: REEXAMINING THE 'SACRED' IN THE FILM-MAKING OF DAVID GULPILIL AND ROLF DE HEER
}

\author{
Alison Jasper, University of Stirling, Scotland \\ Literature \& Theology: September 2016
}

\begin{abstract}
In this article I address some of the themes raised at the conference 'Grounding the Sacred' held in July 2015 under the auspices of 'The Sacred in Literature \& the Arts' (SLA) at Australian Catholic University (ACU) Sydney, Strathfield Campus. First of all I discuss the term 'sacred' in relation to the work of nineteenth century sociologist Émile Durkheim for whom the word denoted the objects, practices and assumptions that sustained communal solidarity and fostered dynamic energies whether or not they were conventionally described as 'religious'. In reference to the work of more recent scholars of 'critical religion' however, I go on to suggest that the terms 'religion' and 'the sacred' derive from a predominantly western, patriarchal and colonial context, forming part of a complex network of interconnected categories that represent a distinctive and dominant discourse of power constructing a privileged identity through hostile Othering or exclusions. Arguably, in the Australian mainstream a discourse of 'religion' imported largely by Christian settlers from the west over the last two hundred years has been employed to exclude Aboriginal ways of understanding the world, for example by promoting the category of 'land' as an exploitable, God-given human possession. Nevertheless, drawing on the work of Julia Kristeva I understand that an encounter with the Other-whether the Aboriginal or the balanda-can be viewed differently: as a zone of properly disturbing but also creative possibility. However, it remains very important to acknowledge the power imbalances that are still embedded within such encounters and the consequent risks to indigenous Australians of further dislocation and dispossession. This idea is explored through a consideration of the collaborative film-making of David Gulpilil and Rolf de Heer and, in particular, of two films: Ten Canoes (2006) and Charlie's Country (2013).
\end{abstract}

Émile Durkheim, the nineteenth century sociologist, defined religion in social terms. For him what is referred to as 'religion' is the way in which groups or societies operate to create and maintain their solidarity and cohesive energies. More specifically he explains this as 'a unified system of beliefs and practices 
relative to sacred things, that is to say, things set apart and forbidden'.1 In developing this view of religion he employed a distinction between the sacred and the profane: the sacred he associates primarily with practices that are thought to guarantee the group's dynamic energies and sources of power and are hedged around by taboos. The profane he implies, represents everything else and the two terms are thus defined by what he calls their 'heterogeneity'. ${ }^{2}$ It has been suggested that Durkheim began his investigation into 'religion' as a response to social upheavals at the end of the nineteenth century in his own country, France, and that he was motivated to write his best known work in this field, The Elementary Forms of Religious Life, by the hope that in identifying certain 'forms of religion' as the springs of social solidarity and dynamism, he might uncover clues to contemporary social regeneration. ${ }^{3}$ In this way Durkheim implied that the term 'religion' had application beyond and outside institutions, places or perspectives conventionally identified at the time as 'religious' or 'sacred'. In this way he raised a question as to why words such as 'religious' or 'the sacred' were not more widely applied. What is it for example that debars devotion to the Constitution of the United States or to the tenets of economic liberalism from being included under these headings? A 'Durkheimian' understanding of 'religion' and 'the sacred' would encompass both examples since they clearly represent unified systems of beliefs and practices relative to normative assumptions and values that are surrounded by taboos in the sense that devotees believe they cannot be challenged without dire and terrifying

\footnotetext{
${ }^{1}$ Émile Durkheim, The Elementary Forms of Religious Life (1915), trans. Carol Cosman (Oxford: Oxford University Press, World's Classics, 2008), p. 46.

${ }^{2}$ Durkheim, Elementary Forms, p. 38

${ }^{3}$ Ivan Strenski, Thinking about Religion: An Historical Introduction to Theories of Religion (Oxford: Blackwells, 2006), p.302.
} 
consequences. A common response to this question of course, is that these matters are not 'religious' but 'political' or 'economic' or 'secular'. This, however, ignores the interdependence of these terms and their mutual self-exclusions. What is 'political' or 'economic' or 'secular' besides the exclusion of the other categories? Such concepts are dependent on each other and this recognition thus prompts a further question about whose interests the construction and maintenance of these mutually self-exclusory categories serves. Although Durkheim himself continued to use the terms 'religion' and 'the sacred' without further interrogation, it could be said that he paved the way for later commentators and critics ${ }^{4}$ to identify the naming of these self-exclusive categories linked together within complex, mutually dependent networks of assumptions, ideas and forms of praxis, as an exercise of power. ${ }^{5}$

One such complex modern network that originates within European modernity (Fitzgerald in Stack, Goldenberg \& Fitzgerald (eds), 2015, 267) takes as a given 'the private ownership of the earth, including the right to buy and sell it for purely personal gain, unencumbered by any effects the practice might have on the lives of other people or the environment'. This, 'historically peculiar idea, one which would have been incomprehensible to most of the peoples who ever

\footnotetext{
${ }^{4}$ See Timothy Fitzgerald, 'Encompassing Religion, privatized religions and the invention of modern politics', in Timothy Fitzgerald (ed.), Religion and the Secular: Historical and Colonial Formations. (London, Oakville: Equinox, 2007), pp. 211-140; Trevor Stack, Naomi Goldenberg and Timothy Fitzgerald (eds), Religion as a Category of Governance and Sovereignty (Leiden, Boston MA: Brill, 2015).

${ }^{5}$ See Timothy Fitzgerald, http://criticalreligion.org/2015/08/27/postmodernism-postcolonialism-andthe-private-property-society/ The Critical Religion Association (www.criticalreligion.org), Thursday 27 August. (Last accessed 28.10.15.)
} 
existed' fits comfortably into a 'masculinist fiction of the naturally possessive individual and his supposed rights' 6 that characterizes dominant cultural discourses at the present time. Other symbolic terms within this network of assumptions are the Christian emphasis on human dominion (benevolent or otherwise) taken from readings of the biblical story of creation (Genesis 1:28), and contemporary essentialisations of 'market forces' or 'nation states'. Accommodating synergetic relationships that accord equitable value to human and non-human aspects of the material universe is a huge challenge for people formed within this dominant network of assumptions about possession and ownership that is linked to the discourses of 'religion' and 'the sacred' in ways that are neither neutral nor innocent. Consider, for example, a widespread modern western myth that categorizes 'religion' as inherently violent, thus helping to disguise the ways in which a great deal of violence is instigated and carried out by powers expressly defining themselves as 'secular'7. In other contexts, 'religion' is feminized both in terms of its assumed feminine tendencies towards the irrational and the violent ${ }^{8}$ and in the light of its devalued status as 'not very important'. .9 As vestigial powers, ${ }^{10}$ so-called 'religious' institutions (like

\footnotetext{
${ }^{6}$ See Fitzgerald, The Critical Religion Association (Last accessed 28.10.15).

${ }^{7}$ See William T. Cavanaugh, 'Colonialism and the Myth of Religious Violence' in Fitzgerald (ed.), Religion and the Secular, pp. 241-262.

${ }^{8}$ See Pamela Anderson, Feminist Philosophy of Religion: The Rationality and Myths of Religious Belief (Oxford: Blackwells, 1997); Rose Weltz (ed.), The Politics of Women's Bodies: Sexuality Appearance and Behavior (New York: OUP, 2003); bell hooks, Black Looks: Race and Representation (London \& NY: Routledge, 2014).

9 Barbara Welter, 'The Feminization of American Religion: 1800 - 1860', in Mary Hartman and Lois W. Banner (eds), Clio's Consciousness Raised: New Perspectives on the History of Women (New York, Hagerstown, San Franciso, London: Harper Colophon Books, 1974), p. 138.

${ }^{10}$ See Naomi Goldenberg, https://audioboom.com/boos/776837-1-what-is-avestigial-state 2012. (Last accessed 28 October 2015.)
} 
the Christian Churches for example) can thus be more easily ignored when they do occasionally attempt to flex their muscles and make inconvenient claims to forms of sovereignty that conflict with the normative values of western neoliberalism. A relevant example might be the recent publication of the Papal encyclical, Laudato si. ${ }^{11}$ Here we certainly see efforts being made by the Head of the Roman Catholic Church to challenge attitudes and assumptions. However as a 'vestigial power' in the sense described above, what we also see is how the 'Papal brand' (as religious-not-secular) is positioned in relation to (secular-notreligious) institutions such as the European Union or the United Nations. Without an invitation the (religious-not-secular) Pope has no ingress into their privileged (secular-not-religious) discussions of climate change and environmental targets. Thus these differing ascriptions indicate how the language of 'religion' and of the religion/secular binary ${ }^{12}$ rather than identifying substantive entities, are more aptly defined as features within a (gendered and colonial) discourse of power. This is not to suggest that what is being discussed in these terms is therefore insignificant or that it has to be understood in reductive terms. It does suggest however that the generally accepted definition of these expressions derives from a privileged matrix or system of meanings and a desire to maintain that privilege.

Naming 'religion' or 'the sacred' as an exercise of power in this way also connects the terms to an agenda of exclusions. If one of Durkheim's key underlying concerns was to find sources for regenerating a sense of national identity in the wake of nineteenth century upheavals in France, in the twenty-

${ }^{11}$ Laudato si (On Care for Our Common Home). Papal Encyclical, 2015.

${ }^{12}$ See Fitzgerald, 'Encompassing Religion', pp. 213-214. 
first century, global conflicts, dislocations and migrations-and our increased consciousness of them through the media-have raised the stakes in relation to 'the Other'. If there is a tendency to understand this contemporary global dynamic in terms of a thoroughly hostile interpretation of 'Otherness' this itself has provoked in some a countervailing response according to which there is a desire to address the stranger, settler, foreigner or even heretic, without reducing them to a dangerous pollutant, perpetually threatening or conversely perpetually defining a group solidarity. This is the kind of view expressed in the work of Julia Kristeva for example. If the trope of the Other implies something disturbing and unsettling, being unsettled, she argues, also produces dividends in personal and communal terms. An incomer or foreigner herself-travelling as a young student from Soviet Bulgaria to Paris in the early 1960s-Kristeva searches out examples of how crossing boundaries between apparently heterogeneous difference/s can be fruitful. For example breaking into the blissful union of mother and neonate, ${ }^{13}$ the 'father of individual pre history' brings the psychic advantages of language and symbolism. Acknowledging the outsider as the hidden face of our own identity shatters a limiting complacency, indicating to ourselves that we are always also awkward inveterate 'foreigners, unamenable to bonds and communities'14). And in relation to the sacred she asks:

[w] hat if the [it] were not the religious need for protection and omnipotence that institutions exploit but the jouissance of that cleavageof that power/powerlessness-of that exquisite lapse. ${ }^{15}$

\footnotetext{
${ }^{13}$ See Julia Kristeva, Revolution in Poetic Language, trans. Margaret Waller (New York: Columbia University Press, 1984); Julia Kristeva, In the Beginning Was Love: Psychoanalysis \& Faith, trans. A. Goldhammer (New York: Columbia University Press, 1987).

${ }^{14}$ Julia Kristeva, Strangers to Ourselves, trans. Leon S. Roudiez (New York: Columbia University Press, 1988), p.1.

${ }^{15}$ Catherine Clément and Julia Kristeva, The Feminine and the Sacred, trans. Jane
} 
In other words, if naming 'the Other' is a power play, setting an agenda of exclusion, then breaching the boundaries between heterogeneities opens up a zone of creative possibility. Although something is thoroughly dismantled and dislocated, a more intensely articulate and capable subjectivity can emerge.

To summarize so far: it can still be said that Durkheim's analysis of the ways in which people construct systems of beliefs and practices is insightful whether or not one names them as 'religion' or 'the sacred'. Yet here, 'religion' and 'the sacred' have been read as terms that do not indicate fixed essences, things in the world or a category that is 'sui generis'. Instead, the discourses of 'religion' and of 'the sacred' make sense and are mobilised within interconnected networks of categories, themselves invested with differential elements of power not excluding gendered power and this is a process that is not fixed, neutral or innocent. In relation to Kristeva's readings, it also makes sense to suggest that bounded networks that frame our sense of cohesive identity as various kinds of communities are also sometimes usefully and creatively challenged. Dismantled and renegotiated they cause trauma of greater or lesser impact yet the process leads to altered patterns of inclusion allowing for creative encounters with the Other. By way of illustration, let us turn then to the work of the Aboriginal actor and dancer David Gulpilil. As collaborator and renegotiator, he expresses through his connections with non-Aboriginal professionals in the arts the complex demands of marking Aboriginal communal solidarity and distinctiveness in contemporary circumstances. Whilst clearly indicating he 
understands that this solidary and distinctiveness is always under threat from the non-Aboriginal 'Other', he resists simplistic fantasies of hostility in response.

Of course, the profound difficulties that lie in the way of any attempt to weave together networks constructed within different mainstream, elite 'western' and Aboriginal Australian communities cannot be underestimated. One significant difficulty takes us back to the discussion of land ownership and the European colonial view that draws on past Christian orthodoxies about human dominion over the non-human world; orthodoxies it should be said that in recent years have sometimes been contested within Churches. ${ }^{16}$ This nonetheless persistent inference is fundamentally at odds with an Aboriginal understanding of 'country' which, in distinction,

...draws attention to what we may gloss as people-to-environment, people-to-people and people-to-cosmos relations. In the Australian context, the idea of Country has not generally implied a nationalistic claim of exclusive rights from Indigenous peoples. It has more commonly been used as a statement of connection, belonging, and affinity. ${ }^{17}$

The conference for which this paper was originally written was called 'Grounding the Sacred'. A second or alternative title reflecting Aboriginal values and assumptions might perhaps have been framed in terms of this alternative non-possessive notion of 'grounding'. For the most part of course, mainstream Australian society moves forward with minimal concessions made to the interconnected subaltern beliefs, practices and assumptions of the indigenous

\footnotetext{
${ }^{16}$ See Encyclical, Laudato si; Sean McDonagh, Climate Change. The Challenge to All of Us (Dublin: The Columba Press, 2006); Sean McDonagh, Dying for Water (Dublin: Veritas Publications, 2003); Sean McDonagh, The Greening of the Church (New York: Continuum International Publishers, 1990); Sean McDonagh, To Care for the Earth: A Call to New Theology (Rochester, VT: Bear \& Co, 1987).

${ }^{17}$ Minna Hsu, Richard Howitt, and Chun-Chieh Chi, "The idea of "country": Reframing post-disaster recovery in indigenous Taiwan setting', in Asia Pacific Viewpoint Volume 55, no 3 December 2014, p. 370.
} 
people. In spite of Kristeva's contention that breaching or crossing over our established boundaries gives scope for creativity and new life, inequitable power dynamics render this a desperately risky activity for the already dispossessed; catastrophic disruption of Aboriginal networks of interconnected assumptions, practices and discourses at work since the first European settlers arrived, means Aboriginal access even to traditional networks is on every occasion now fraught with doubt and discouragement.

There was some effort to acknowledge this at the conference both through a formal 'welcome to country' delivered at its opening by a representative of the Aboriginal community and on behalf of his ancestors from the Sydney area, and also through the inclusion of a collection of paintings by Papunya Tula and Warlayirti Artists presented under the title 'EarthSong'. The collection had passed into the possession of a collector, Lloyd Graham, who was not himself from the Aboriginal community. Nevertheless, by his choice of exhibition space-within the context of a conference about grounding the sacred in a university_-Graham was undoubtedly signalling his desire both to be taken seriously as an authority on the Western Desert Art Movement and as cultural intermediary rather than as the kind of Aboriginal art exploiter we see represented in the film like Samson and Delilah ${ }^{18}$. The Western Desert Art Movement ${ }^{19}$ out of which the exhibits emerged, constitutes one important example of creative cross cultural exchange between Aboriginal and nonAboriginal Australians over the last forty years; one within which there have

\footnotetext{
${ }^{18}$ Warwick Thornton, 2009.

${ }^{19}$ See Vivien Johnson, Papunya Painting: Out of the Desert (Canberra: National Museum of Australia Press, 2006).
} 
been efforts on both sides to acknowledge differences and yet also to work together. Thus the conference handbook makes clear its intention not to be seen in an exploitative light:

Most of these works refer to and embody Aboriginal Law, and thus have at their heart secret/sacred information that cannot be divulged to outsiders. However, 'public' versions of the stories coexist with the deep interpretations, and the former are safe to share. ${ }^{20}$

If the Western Desert Art Movement as a whole indicates one context within which there is an attempt to respect an alternative framework of practices and beliefs relating to the interrelationships between human and non-human worlds, the work in the Australian film industry, with which David Gulpilil has been involved represents another. A growing body of films directed by Aboriginal film-makers or in collaboration with non-Aboriginal directors illustrates efforts to pave the way for a safer renegotiation of boundaries.

Of course, within the context of the Australian film industry as a whole, earlier twentieth century films, when they represented Aboriginal people or themes at all, at first took predictably European and often highly racist perspectives, portraying Aboriginal and Torres Straight Islander people as wild and uncivilised. From the 1930s to the 1950s Aborigines-as in Uncivilised ${ }^{21}$ and Bitter Springs ${ }^{22}$ - were represented 'as an undifferentiated and violent force of nature'23, rather than as human. From the 1970s however, Indigenous actors began to emerge in much more sympathetic roles and a notable early example

${ }^{20}$ Conference handbook, ACU Grounding the Sacred, 2015.

${ }^{21}$ Charles Chauvel, 1936.

${ }^{22}$ Ralph Smart, 1950.

${ }^{23}$ Australian Government. 'About Australia: Indigenous Film' http://www.australia.gov.au/about-australia/australian-story/indigenous-film. (Last Accessed 31.03.16) 
was Nicolas Roeg's 1971 Walkabout in which a very young David Gulpilil starred to international acclaim. Indigenous characters at this period nevertheless remained wrapped in exotic mystification; ${ }^{24}$ they were not portrayed as characters white audiences could relate to very closely. Fortuitously, when the Australian Film Development Corporation (AFDC) was set up in 1970 to address the overwhelming domination of its film industry by Hollywood and occasionally by British interests, ${ }^{25}$ the revival of the film industry's fortunes in general worked through its wider effects in favour of a nascent Aboriginal film industry. Although this infrastructural support was directed towards the making of feature films for largely white Australians, the new injection of funds and sponsorship supported the emergence of Aboriginal talent and creativity in this field. Perhaps most significantly, Essie Coffey's acclaimed My Survival as an Aboriginal (in collaboration with Martha Ansara) was released in 1979. Still working within the context of documentary film-making rather than feature filmmaking, this was nevertheless a first both in the sense that it was directed by women and from an Aboriginal perspective. In the decades following, Aboriginal actors and directors across the whole spectrum of Australian film-making began taking greater control of their own representation. This is evident in what might be seen as block busters directed towards fundamentally white Australian viewers-the Crocodile Dundee franchise ${ }^{26}$ and Priscilla Queen of the Desert ${ }^{27}$ for example. Here representations of Aboriginal people are seen to be moving away from the stereotypical. Arguably too 'the chauvinist jamboree of 1988's

\footnotetext{
${ }^{24}$ See Australian Government. 'About Australia: Indigenous Film'

${ }^{25}$ Stephen Crofts, 'New Australian Cinema', in Geoffrey Nowell-Smith (ed.), The Oxford History of World Cinema (Oxford: OUP, 1997), p. 722.

${ }^{26}$ Peter Faiman, 1986; John Cornell, 1988; Simon Wincer, 2001.

${ }^{27}$ Stephan Elliott, 1994.
} 
Bicentennial (of white settlement)....catalysed black resistance', advancing thinking on Aboriginal land rights and inspiring Aboriginal film-makers to start making in-roads into feature film production. ${ }^{28}$ Building on the earliest features by Aboriginal directors such as Kevin Lucas ${ }^{29}$ and Tracey Moffat, ${ }^{30}$ there is now a significant body of Aboriginal documentary and film. Today there are more Aboriginal directors at work than ever, including most notably Warwick Thornton ${ }^{31}$ and Ivan Sen. ${ }^{32}$

This is not to deny that the power of distribution remains largely in the hands of western companies. Nevertheless, the collaboration between David Gulpilil and Dutch Australian film director, Rolf de Heer has developed and blossomed in this more fertile context as two examples will show, starting with the 2006 feature, Ten Canoes $^{33}$. Gulpilil made the introduction to his community in Arnhem Land in the Northern Territory and suggested de Heer might make a film with them. Although Gulpilil ultimately provided only the voice-over for the film, de Heer went on to work successfully with the community in Ramingining, developing another fruitful directorial collaboration with Aboriginal actor, Peter Djigirr. The film develops out of discussion with the Aboriginal cast-and invokes a set of beliefs and practices (telling stories about the ancestors/making traditional canoes for collecting the eggs of wild geese and addressing

\footnotetext{
${ }^{28}$ Crofts, 'New Australian Cinema', p. 730.

${ }^{29}$ See Black River, 1993.

${ }^{30}$ See Bedevil, 1993.

${ }^{31}$ See Samson \& Delilah, 2009; Art \& Soul, 2010; The Darkside, 2013; Words With Gods, 2014.

${ }^{32}$ See Dreamland, 2009; Toomelah, 2011; Mystery Road, 2013.

${ }^{33}$ DVD Rolf de Heer and Peter Djigirr. UK: Universal Pictures, 2007.
} 
fundamental human problems of how to live well) that frame the representation of a strong and cohesive Aboriginal community, living at a time before the arrival of the balanda or white settler. Directors de Heer and Djigirr develop the film Ten Canoes as a narrative of sacred mythic time interwoven with the day to day concerns of Aboriginal people in historical time. However, although the film is set before the balanda arrives in Australia, these settlers are present as motivation and provocation; their questions about the value of Aboriginal communities and their stories in the world of today hang in the air. The narrative of the film concerns a young man who is warned against pursuing a married woman. The law and the proper way of doing things is established through the telling of a story about the ancestors with a mostly light and humorous touch as the group of ten men work together to construct their boats for the hunt. The story of the ancestors that the elders tell the younger man-a story that also has its darker elements-parallels his story. It too is a story about a young man who covets his brother's wife.

On one level the film clearly sets out to represent and celebrate practices that maintain the solidarity and cohesive energies of these Aboriginal people set apart from other communities and particularly from anything to do with the balanda. It establishes a difference and a perspective within which it is the dominant European forms of Australian culture that are implicitly reversed as Other. The actors go naked as they would have done in precolonial times and as befitting ancestral time. At the same time, the Other makes its challenging appearance within this apparently purely Aboriginal narrative. Thus the plot of the film includes a pivotal encounter with an Aboriginal stranger who arrives 
without warning or clear purpose. His unexplained appearance unsettles the ten ancestors of the story and leads eventually to a death as well as to a conclusion to the story. The dynamic impact of this incursion and its consequences is the mythic framework through which traditional law and values are restated andthrough the distribution of the film—intentionally brought to bear in some way, however small, on the defining impact of mainstream Australia.

In another way—on a different level—the film's afterlife as a DVD incorporates additional footage in the form of a film about the filming ${ }^{34}$. This makes an equally strong if slightly different statement. The film of the filming is an exercise-made we have to assume with co-director Djigirr's approval, since several filmed interviews with him are included-that draws attention to the cinematic work as a self-conscious search for new words and new ways to express the distinctive nature of interconnected Aboriginal networks of beliefs and practices both in relation to the past and to the twenty-first century in which the balanda represents the unavoidable challenge to survival and safety. In this context, Djigirr speaks about Aboriginal 'law' and 'culture' using these words to define his intentions in this work. Yet the film of the filming emphasises the fact that this is not a simplistic refutation of all things new and non-Aboriginal but a highly sophisticated acknowledgement of and engagement with mainstream Australian values and culture in recognition of their devastating effects. Djigirr, Gulpilil and their community thus take on for themselves not simply the role of custodians but also potential shapers of new interconnected networks, exposing

\footnotetext{
${ }^{34}$ This film is also available separately from the DVD of Ten Canoes as Balanda and the Bark Canoes - The - Making "Ten Canoes". http://nfsa.gov.au/collection/filmaustralia-collection/program-sales/search-programs/program/?sn=9057
} 
and challenging the ways of the balanda but also indicating a willingness to renegotiate in order to maintain solidarity and generate energy for the twentyfirst century in Ramingining, Australia and even globally. On set, Djigirr describes how he sees the work as a way of recording and promoting the community's culture and laws echoing the educational characteristic of Essie Coffey's earlier documentary. However Djigirr's presence in a directorial role also indicates that he believes that he and his fellow actors have the capacity to do this through deliberate appropriation of contemporary knowledge. This is illustrated not only in his involvement with the technology of film-making but also in terms of studying the works of D. F. Thomson (1901-1970). Thomson, a white anthropologist, recorded descriptions and made meticulous drawings of Aboriginal life and culture in the early twentieth century. Here, in the film of the film-making, his work is shown to be an important resource as the elders of the twenty-first century Aboriginal community have lost touch and familiarity with some of the skills required to make the canoes of the film's title. This film then comes across as a bid to make something new by showing that what draws the community or group together comes out of a risky collaboration-often uncomfortable and fraught with difficulties as de Heer makes clear-with the stranger (within and outside), bringing about new relationships, new ways of thinking and new beginnings.

In portraying the mythic narrative evoking the beliefs and practices relating to the ancestors, the main protagonists of Ten Canoes are all male-in both the film and the film of the filming. Female figures feature but mainly as a plot device, setting up the action much as Helen's abduction by Paris is the 
occasion of epic masculine adventuring_and posturing-in Homer's Iliad. Women are not strong or developed characters in this film as it could be said, for example, of Molly Craig in Rabbit Proof Fence, ${ }^{35}$ or of the female lead in Samson \& Delilah. ${ }^{36}$ Without wanting to concede too much, we could suggest however that through the making of the film about the film we are made aware of these gender issues quite deliberately; male Aboriginal sensibilities are irritated and some established assumptions are challenged whilst women's voices are silent on the subject. Yet the issue is revealed even if it is not resolved. It is a work in progress. Ten Canoes thus represents a courageous attempt to challenge the dominance of mainstream twenty-first century Australian networks of knowledge, assumption and practice, looking to rewrite boundaries and identities in ways that are different, creative and also more ethically justifiable. The success of this venture, or indeed of the Aboriginal film-making industry as a whole, in shifting thinking about Aboriginal ways of being in the world is harder to judge, although Ten Canoes has certainly attracted some attention. It won six Australian Film Institute (AFI) awards indicating strong critical approbation beyond its Aboriginal context.

The second collaboration between David Gulpilil and Rolf de Heer to which I want to draw attention is ${ }^{37}$ This has been similarly successful in critical terms. Gulpilil won 'best actor' award at the 2014 Cannes Film Festival in the Un Certain Regard section for his role in this film. It was also screened in the Contemporary World Cinema section at the 2014 Toronto International Film

\footnotetext{
${ }^{35}$ Phillip Noyce, 2002.

${ }^{36}$ Warwick Thornton, $2009 .$.

${ }^{37}$ DVD Rolf de Heer, New York: Visit-Films, 2013.
} 
Festival and won the Best Fiction Prize and the Youth Jury Prize at the International Film Festival and Forum on Human Rights (FIFDH) in Geneva in 2015. It is a different kind of film from Ten Canoes, touching more directly on Gulpilil's life and experience as an Aboriginal Australian who was born in the bush and spent formative years acquiring the arts and skills of an ancient people before moving into troubling engagement with modern mainstream Australia. Charlie's Country addresses the exploitation of the land and the destruction of Aboriginal networks of understanding and evaluation more directly than Ten Canoes. It offers a poignant illustration of how things have passed beyond any possibility of simple restoration. Thus whilst the social and cultural capital Aboriginal people possess is systematically targeted and dismantled-they are not to be trusted with their own medical care, housing or policing-they remain excluded from the dominant frameworks of value through financial exchange. The effort to sustain the semblance of traditional community evoking the value of 'country' is shown within this film to be overwhelmingly difficult within contexts in which money is the most significant currency and in terms of the fixed patterns of residence, transport, education, employment and law that have been so firmly established within mainstream Australian society. This may also be a problem for mainstream Australian society but its effects on Aboriginal communities attempting to find space and context for differing traditional forms of value and integrity are that much more devastating and immediate.

In the film, Charlie and his friend, short of food and of money to buy the food that is on sale in regulated shops, reflect that there is plenty of food in the bush—it's like a supermarket! They take their car and eventually find and shoot 
a water buffalo loading it on the bonnet to drive home. But the local police-a metaphor for mainstream white Australian values in conflict with Aboriginal communities perhaps-prove that the bush is not at all like a supermarket, a mainstream Australian industry that will brook no rivals! They intervene and confiscate both the illegal kill and the unlicensed guns. Charlie and his friend enjoy a pyrrhic victory as much as they can, anticipating that the police will find it hard to dispose of a massive buffalo carcass already beginning to play host to swarms of flies in the heat of the day, but they are still hungry and they are still literally and figuratively disempowered. Charlie struggles to adjust to the recognition that although he retains knowledge and understanding of how Aboriginal society is put together and works, he cannot restore the whole community's dynamic cohesion on his own. He has skill and memory for dance, painting, teaching and can survive for a while 'on country' with weapons he makes himself, but the Aboriginal notions that sustained whole communities in their nomadic journeys across the land in search of water and food in the precolonial past are gone. They have been dismantled as much by widespread devaluation of the group's interconnected economy of story-telling and ritual practices as by the devastating exploitation of the land through the dis/possessions of mining and building. On his own, Charlie fairly quickly falls prey to the inevitable uncertainties of life in the bush, to be rescued and then abandoned once more in the northern city of Darwin where he leaves the alien territory of a hospital and falls in with a group of doubly displaced Aboriginal people. This group of inconvenient and untidy Aboriginal travellers exists on the margins of the urban mainstream, disconnected from Aboriginal traditions and communities with no way into mainstream Australia. 
Exclusion and dispossession of the Aboriginal Other are themes from the beginning of the film where Charlie-whose memories here are also David Gulpilil's - takes out of his bag, the photograph he has kept from his childhood when he danced naked for the Queen at the opening of the Sydney Opera House in 1973. Briefly shining in mainstream Australian life, Charlie, like David Gulpilil, eventually ends up in prison. In a witty yet devastating reprisal of the typical 'prison movie' sequence in which the new prisoner is divested of his or her individual identity, the camera focuses on Charlie's hair being shaved in what is surely an invocation of the widespread Aboriginal practice of cutting hair and shaving as a gesture of mourning for the dead. Charlie is locked into hostile shaven monotony; contained within dreary routines as implicitly angry and selfpunishing as some of the mourning traditions Durkheim recalled from the nineteenth century work of Brough Smyth ${ }^{38}$ and Spencer and Gillen. ${ }^{39}$ Nevertheless this film says very clearly that the vision of an Aboriginal future that returns to the world of Ten Canoes is untenable. Of course mourning is not only a response that is appropriate for Charlie (and David Gulpilil), forced to recognize the extent of his own dispossession and exclusion but also for the nonAboriginal viewer, recognizing what we have all lost through greed, carelessness or misunderstanding. The mainstream Australian penal system is an apt metaphor for the much wider sense of limitation and imprisoned sensibility within mainstream (and more broadly 'western') global contexts.

\footnotetext{
${ }^{38}$ Robert Brough Smyth, The Aborigines of Victoria (Melbourne: J. Ferres, 1878).

${ }^{39}$ Durkheim, Elementary Forms, pp. 292-293.
} 
Nonetheless as a result of the work of both actor and film-maker, it could be said a glimmer of creative optimism emerges in this film about the devastation of a whole way of life. The narrative concludes with some measure of recovery. Charlie finally agrees to teach the Aboriginal boys the rituals and dances whose secret knowledge he thus reclaims. And of course, as an actor and dancer who has now won numerous awards such as the Australia Council's National Indigenous Arts Red Ochre Award in 2013 for his wider contribution to the Arts, Gulpilil himself can, in some ways, claim to have broken down the exclusion of the Other and to have partaken with his non-Aboriginal collaborators in the renegotiation of a different dynamic and cohesive group. But in terms of a wider vision for the future, it is perhaps more significantly in the future of Aboriginal film-making in conjunction with non-Aboriginal collaborators as a wider enterprise-to which creative and courageous artists such as Gulpilil are drawn—that the greatest potential for dismantling and renegotiating boundaries and liberating the imprisoned sensibility of the mainstream is held.

In conclusion I have addressed what were some of the themes of the original conference on grounding the sacred in art, first of all by discussing the term 'sacred' in relation to the work of Émile Durkheim for whom the word denoted the objects, practices and assumptions that sustained communal solidarity and fostered dynamic energies whether or not they were conventionally described as 'religious'. In reference to the work of more recent scholars of 'critical religion' however, I have suggested that the terms 'religion' and 'the sacred' derive from a predominantly western, patriarchal and colonial 
context, forming part of a complex network of interconnected categories that represent a distinctive and dominant discourse of power constructing a privileged identity through hostile Othering or exclusion. Arguably, in the Australian mainstream a discourse of 'religion' imported largely by settlers from the west over the last two hundred years has been used to help exclude Aboriginal ways of understanding the world, for example by promoting the category of 'land' as an exploitable, God-given human possession. Nevertheless, drawing on the work of Julia Kristeva I understand that an encounter with the Other-the Aboriginal or the balanda — can be viewed differently, as a zone of disturbing but also creative possibility. Normative and oppressively exclusive frameworks of meaning and value may be established in response to a need 'for protection and omnipotence' that powerful and privileged institutions exploit. Yet Kristeva suggests this is not the only way to frame the stranger or alien. Actors and directors like Peter Djigirr, David Gulpilil and Rolf de Heer thus exemplify a different and more creative approach through their collaborative involvement with the poetics and technologies of the contemporary art of filmmaking. It is clearly important not to forget the imbalances that remain embedded within such encounters and the consequent risks to indigenous Australians particularly of further dislocation and dispossession. However in this film-making work we can perhaps begin to see beyond the ever-present danger of loss and dissolution, something of Kristeva's 'exquisite lapse' where we trade the dynamics of power or powerlessness for the birthpangs/ jouissance of emerging ideas, identities, energies and revolutionary relationships. 
